\title{
Red Blood Cells, a Source of Factors which Induce Neisseria gonorrhoeae to Resistance to Complement-mediated Killing by Human Serum
}

\author{
By P. V. PATEL, ' P. M. V. MARTIN, ${ }^{2}$ M. GOLDNER, ${ }^{3}$ N. J. PARSONS ${ }^{1}$ \\ AND H. SMITH ${ }^{1 *}$ \\ 1 Department of Microbiology, University of Birmingham, PO Box 363. \\ Birmingham BIS 2TT, UK \\ 2 Unité d'Ecologie bactérienne, Institut Pasteur, 75015 Paris, France \\ ${ }^{3}$ Department of Microbiology, University of Toronto, Toronto, Canada
}

(Received 19 March 1984 ; revised 5 June 1984)

\begin{abstract}
Lysates of guinea pig or human red blood cells $(\mathrm{RBC})$ contain far more of the factors that induce resistance in gonococci to complement-mediated killing by fresh human serum than do plasma or serum. As was previously found with serum, most of the resistance-inducing activity of guinea pig RBC lysates was found in ultrafiltrates with molecular weights of less than 5000 . In contrast, and as with human serum, most of the resistance-inducing activity of human RBC lysates did not pass ultrafilters which removed molecules of less than $\mathbf{5 0 0 0}$ daltons, although some active material of low molecular weight was present.
\end{abstract}

\section{INTRODUCTION}

The resistance to complement-mediated killing shown by gonococci taken from patients is important in the pathogenesis of gonorrhoea (Brooks et al., 1978). This resistance can be demonstrated by tests with human serum on isolates before subculture (Brooks et al., 1978; Ward et al., 1970). Many isolates, however, particularly those from urethral exudates, lose resistance on subculture (Ward et al., 1970). This unstable type of resistance was initially investigated using a guinea pig model. Gonococci grown in plastic chambers implanted subcutaneously into guinea pigs showed a resistance to killing by human serum which was gained in vivo and lost in vitro in a phenotypic manner (Rittenberg et al., 1977). The resistance was induced in vitro in $3 \mathrm{~h}$ at $37^{\circ} \mathrm{C}$ by guinea pig chamber fluid, by guinea pig serum and by ultrafiltrates of the serum in a defined medium containing $0.1 \%$ bovine serum albumin (BSA) (Goldner et al., 1979; Veale et al., 1980, 1981; Patel et al., 1984). Recently, the acid- and heatlabile resistance-inducing factor (RIF) in the ultrafiltrates (Veale et al., 1980) has been purified into a fraction containing glucose, cysteine, aspartic acid, serine, threonine, glutamic acid, glycine, alanine and lysine (Patel et al., 1984).

Turning to the human situation, about $20 \%$ of over 200 sera had resistance-inducing activity (Martin et al., 1981, 1984) but to a lesser extent than guinea pig sera (Martin et al., 1981). On ultrafiltration some resistance-inducing activity was found in heat- and acid-labile low molecular weight fractions, but in contrast to guinea pig sera far more activity remained in the fractions of high molecular weight (Martin et al., 1981). The relevance of human RIF to the resistance of genital tract gonococci was shown when cervical secretions and seminal plasmas from healthy people and vaginal exudates from patients with non-gonococcal vaginitis induced gonococci to resistance in vitro (Martin et al., 1982). Furthermore, 30 recent isolates of gonococci regained resistance, which had been lost on subculture, after incubation with the guinea pig RIF

Abbretiations: RBC, red blood cells; RIF, resistance-inducing factor. 
(Martin et al., 1983), which is similar to, if not identical with, the human serum factor of low molecular weight (Martin et al., 1981). The possible influence of the RIF on disease patterns was indicated by the fact that sera of female patients suffering their first infection contained signifcantly more samples showing high resistance inducing activity than did sera of uninfected controls (Martin et al., 1984); paradoxically, no sample of serum from female patients with gonococcal salpingitis had high resistance-inducing activity (Martin et al., 1984). Clearly, the RIF is important in the pathogenicity of gonoccoci and may influence the pattern of gonorrhoea. $A$ greater supply is needed for further research.

Two pieces of evidence indicated that red blood cell (RBC) membranes may be a source of RIF. First, the resistance-inducing activity of both human and guinea pig serum was increased by leaving the serum in contact with the blood cell clot for $24-48 \mathrm{~h}$ before removal (Martin et al., 1981 ; P. M. V. Martin, P. V. Patel N. J. Parsons and H. Smith unpublished observations; Patel et al., 1984). Second, the nature of the low molecular weight RIF purified from guinea pig serum was similar to glucose- and cysteine-containing glycopeptides which are set free from fresh human RBC in mildly hypertonic saline (Weiss et al., 1971; Patel et al., 1984). These peptides appear to be constituents of the membranes rather than enzymic breakdown products of the large glycoproteins of RBC membranes, most of which appear not to contain glucose (Gahmberg, 1981).

This paper shows that water-lysed guinea pig and human RBC, and their ultrafiltrates with molecular weights of less than 5000 , had a much greater ability to induce gonococci to resistance to killing by human serum than the analogous sera and fractions.

\section{METHODS}

Bacterial strains and growth conditions. Neisseria gonorrhoeae [serum sensitive BS4 (agar)], media (including defined medium), culturing and counting procedures were as described previously (Penn et al., 1976; Veale et al., 1981 ; Martin et al., 1981 ; Patel et al., 1984).

$R B C$ lysates and plasma from guinea pig and human blood. Blood $(7-15 \mathrm{ml})$ was obtained by cardiac puncture from guinea pigs (male, Dunkin-Hartley) under anaesthesia (Sagatal, $0.5 \mathrm{ml}$ per $\mathrm{kg}$ body wt) and citrated ( $5 \mathrm{mg}$ trisodium citrate $\left.\mathrm{ml}^{-1}\right)$. After centrifuging $\left(1500 \mathrm{~g}, 10 \mathrm{~min}, 4^{\circ} \mathrm{C}\right)$, the plasma was separated and stored at $-20^{\circ} \mathrm{C}$ until required. The cell suspension was washed once with a volume of isotonic saline $(0.3 \mathrm{~m}-\mathrm{NaCl})$ equal to that of the removed plasma. An equal volume of sterile water was added to lyse the RBC. The lysate was centrifuged $\left(1500 \mathrm{~g}, 20 \mathrm{~min}, 4^{\circ} \mathrm{C}\right.$ ) to remove cellular debris and the supernatant was stored at $-20^{\circ} \mathrm{C}$ until required. The volume obtained was approximately equal to that of the original blood and twice that of the plasma.

Human peripheral blood $(7-15 \mathrm{ml}$ ) was treated similarly except that the buffy coat was removed from the RBC deposit as well as the plasma.

Ulirafiltration of RBC lysates and plasma. This was as described by Patel et al. (1984) for guinea pig serum, but using one $43 \mathrm{~mm}$ Diaflo membrane at each stage for every sample of lysate or plasma from 7-15 ml of blood. After filtering through XM-50 membranes (nominal cut-of 50000 daltons) and washing, the filtrates and washings were pooled and filtered through a YM-5 membrane (nominal cut-off 5000 daltons). The filtrate was freeze dried. For biological testing, it was dissolved in a volume of water equal to that of the original RBC lysate or plasma (half that of the lysate). The poorly active ultrafiltrates from human RBC lysates were dissolved in one-fifth of that volume, although the results are quoted in Table I with respect to the original volume.

Generation of serum resistant gonococci, test for resistance to killing by fresh human serum and an approximate assay of RIF in samples. These were as described by Patel et al. (1984). The resistance-inducing activities of RBC lysates, plasmas, YM-5 membrane filtrates and extracts of intact RBC are quoted as the concentration $(\%, v / v)$ needed in the standard test to convert $50 \%$ of the serum sensitive gonococci to resistance.

\section{RESULTS}

\section{The much greater content of RIF in RBC lysates and their ultrafiltrates compared with} corresponding plasmas and their ultrafiltrates

The resistance-inducing activities of guinea pig plasma and its ultrafiltrate (Table 1) were similar to those of guinea pig serum and its ultrafiltrate (Patel et al., 1984). In contrast, the RBC lysates were 40 - to 80-fold more active with respect to the original sample of blood. As with guinea pig serum (Patel et al., 1984), the majority of the resistance-inducing activity was found in the YM-5 filtrate. 
Table 1. Resistance-inducing actirity of RBC lysates and plasmas from guinea pig and human blood and their filtrates through Diaflo YM-5 membranes

These results are typical of six experiments with different batches of guinea pig blood and seven experiments with different batches of human blood.

\begin{tabular}{|c|c|c|c|c|}
\hline \multirow{3}{*}{$\begin{array}{l}\text { Sample of } \\
\text { blood }\end{array}$} & \multicolumn{4}{|c|}{$\begin{array}{l}\text { Concn }\left({ }^{\circ}, v / v\right) \text { inducing } 50^{\circ} \text { of the standard inoculum of } \\
\text { strain BS4 (agar) to resistance to killing by fresh human serum }\end{array}$} \\
\hline & \multicolumn{2}{|c|}{ Plasmat } & \multicolumn{2}{|c|}{ RBC lysate } \\
\hline & Original & YM-5 filtrate & Original & YM-5 filtrate \\
\hline Guinea pig & & & & \\
\hline $\begin{array}{l}1 \\
2\end{array}$ & $\begin{array}{l}40 \\
42 \\
22\end{array}$ & $\begin{array}{l}60 \\
40 \\
26\end{array}$ & $\begin{array}{l}\text { Toxic } \$ \\
0.5 \\
0.4\end{array}$ & $\begin{array}{l}1 \\
0 \cdot 4 \\
0 \cdot 8\end{array}$ \\
\hline Human & & & & \\
\hline $\begin{array}{l}1 \\
2 \\
3\end{array}$ & $\begin{array}{r}>90 \\
58 \\
>90\end{array}$ & $\begin{array}{l}>90 \\
>90 \\
>90\end{array}$ & $\begin{array}{c}\text { Toxic } \$ \\
1.0 \\
2.3\end{array}$ & $\begin{array}{l}30 \\
55 \\
80\end{array}$ \\
\hline
\end{tabular}

- See text for details of assay of resistance-inducing activity.

† The volume of plasma and its filtrate is half that of the original blood and the RBC lysate and its filtrate: the results have been adjusted so that they relate to the $\mathrm{RBC}$ lysate.

\$ These lysates killed the gonococci in the test for resistance-inducing activity.

The results on human plasma and its ultrafiltrate were similar to those obtained for human serum and its ultrafiltrate, where only about $20 \%$ of serum samples were active and activity could be detected only in a 10-fold concentrated YM-5 filtrate (Martin et al., 1981). Three human RBC lysates were toxic for gonococci, but the other four samples were far more active in resistance-inducing activity than the human plasma and approached the activity of guinea pig RBC lysates. However, as with biologically active human sera (Martin et al., 1981), only a small proportion of the total resistance-inducing activity was recovered in the YM-5 filtrate. Nevertheless, all seven YM-5 filtrates from RBC lysates showed significant activity without concentration, in contrast to the situation with samples from serum (Martin et al., 1981).

Like the low molecular weight RIFs from guinea pig and human sera (Veale et al., 1980; Martin et al., 1981) the resistance-inducing activities in the YM-5 filtrates from the RBC lysates were heat- and acid-labile. More than $90 \%$ of the standard inoculum of strain BS4 (agar) was converted to resistance by two different YM-5 filtrates from human RBC lysates and by two filtrates from guinea pig $\mathrm{RBC}$ lysates, but less than $5 \%$ were converted to resistance after the four filtrates had been either heated for $1 \mathrm{~h}$ at $75^{\circ} \mathrm{C}$ at $\mathrm{pH} 7$ or for $1 \mathrm{~h}$ at $37^{\circ} \mathrm{C}$ at $\mathrm{pH} 2$.

\section{DISCUSSION}

Clearly, RBC are a better source of RIF than serum and this applies to both guinea pig and human blood. The much larger quantity of low molecular weight RIF from lysates of guinea pig RBC (40-60-fold compared with serum or plasma) should facilitate investigation of the determinants of gonococcal resistance to complement-mediated killing, since sufficient resistant bacteria can now be obtained for meaningful experimentation. This low molecular weight RIF is heat- and acid-labile as is material obtained from guinea pig serum (Veale et al., 1980; Patel et al., 1984). Nevertheless, the RIF from the guinea pig RBC lysate must be purified by the procedures used for obtaining the RIF from guinea pig serum in order to establish whether the two materials are identical.

The resistance-inducing activity was present in larger amounts in the RBC lysates from human blood than in serum but showed the same pattern on ultrafiltration. Only a small proportion of the total activity was found in the YM-5 filtrates, i.e. in molecules of less than 5000 daltons. 
This low molecular weight material may be similar, if not identical, to the RIF obtained from guinea pig blood since, like the latter and the low molecular weight material from active human sera (Martin et al., 1981), it was acid- and heat-labile. The difference between the resistanceinducing activities of guinea pig and human blood is that the major activity of the latter lies in fractions with molecular weights above 5000 . The chemistry of these larger active molecules needs investigation.

RBC membranes may be the source of the RIF found in guinea pig and some human sera. Low molecular weight glycopeptides are released from fresh intact RBC (Weiss et al., 1971), and the larger inducing materials may be set free by enzyme action. Whether RBC liberate resistance-inducing materials in vivo and whether the resistance-inducing activity of urogenital secretions (Martin et al., 1982) is derived from membranes of RBC, surface mucosal cells or from other sources are matters for future research.

We acknowledge, with thanks, the technical help of Mrs C. Sammons.

\section{REFERENCES}

Broors, G. F., Gotschlich, E. C., Holmes, K. K., SAWYER, W. D. \& YOUNG, F. E. (1978). Immunobiology of Neisseria gonorrhoeae. Washington, DC: American Society for Microbiology.

Grymero, C. G. (1981). Membrane glycoproteins and glycolipids structure, localisation and function of the carbohydrate. In Membrane Structure, pp. 127-160. Edited by J. B. Finean \& R. H. Mitchell. Amsterdam: Elsevier/North-Holland Biomedical Press.

Goldner, m., Penn, C. W., Sanyal, S. C., Veale, D. R. Surth, H. (1979). Phenotypically determined resistance of Neisseria gonorrhoeae to normal human serum: environmental factors in subcutaneous chambers in guinea pigs. Joumal of General Microbiology 114, 169-177.

Martin, P. M. V., Patel, P. V., Parsons, N. J. \& Sumr, H. (1981). Induction of phenotypically determined resistance of Neisseria gonorrhoeae to human serum by factors in human serum. Journal of General Microbiology 127, 213-217.

Martin, P. M. V., Patel, P. V., Parsons, N. J. \& SMITH, H. (1982). Induction in gonococci of phenotypic resistance to killing by human serum by human genital secretions. British Journal of Venereal Diseases 58, 363-365.

martin, P. M. V., Patel, P. V., Parsons, N. J. \& SuITH, H. (1983). Induction of serum resistance in recent isolates of Neisseria gonorrhoeae by a low molecular weight fraction of guinea pig serum. Journal of Infectious Diseases 148, 334.

martin, P. M. V., Patel, P. V., Clay, J. C., Parsons, N. J. \& SMrrH, H. (1984). Induction of serum resistance of Neisseria gonorrhoeae by human serum: a clinical survey of patients with gonorrhoea. British Journal of Venereal Diseases 60, 151-153.

Patel, P. V., Veale, D. R., Fox, J. E., Martin, P. M. V., Parsons, N. J. \& SMrth, H. (1984). Fractionation of guinea pig serum for an inducer of gonococcal resistance to killing by human serum: active fractions containing glucopeptides similar to those from human red blood cells. Joumal of General Microbiology 130, 2757-2766.

Penn, C. W., Sen, D., Venle, D. R., Parsons, N. J., SMTTH, H. \& WITT, K. (1976). Morphological, biological and antigenic properties of Neisseria gonorrhoeae adapted to growth in guinea pig subcutaneous chambers. Journal of General Microbiology $97,35-43$.

Ritrinaero, S. C., Pann, C. W., Parsons, N. J., Venle, D. R. Sumt, H. (1977). Phenotypic changes in the resistance of Neisseria gonorrhoeae to killing by normal human serum. Journal of General Microbiology 103, 69-75.

Veale, D. R., Penn, C. W., Paysons, N. J. \& Suith, H. (1980). Preliminary studies of a factor in guinea pig serum which induces serum resistance in Neisseria gonorrhoeae. Society for General Microbiology Quarterly 7, 188.

Veale, D. R., PenN, C. W. \& SMrth, H. (1981). Factors affecting the induction of phenotypically determined serum resistance of Neisseria gonorrhoeae grown in media containing serum or its diffusible components. Journal of General Microbiology 122, 235-245.

WARD, M. E., WATT, P. J. \& GLYNN, A. A. (1970). Gonococci in urethral exudates possess a virulence factor lost on subculture. Nature, London 227, 382384.

WrLs, J. B., LOTE, C. J. \& Bosinsxi, H. (1971). New low molecular weight glycopeptide containing triglucosylcysteine in human erythrocyte membrane. Nature New Biology 234, 25-26. 